\title{
An observational comparative study of intraocular pressure changes in post-operative cataract patients treated with dexamethasone and difluprednate
}

\author{
Sadhana K. Hingorani ${ }^{1 *}$, Anupama S. Desai ${ }^{1}$, Manisha B. Shastri ${ }^{2}$ \\ ${ }^{1}$ Department of Pharmacology, ${ }^{2}$ Department of Ophthalmology, SMIMER, Surat, Gujrat, India \\ Received: 12 March 2020 \\ Revised: 08 June 2020 \\ Accepted: 09 June 2020 \\ *Correspondence: \\ Dr. Sadhana K. Hingorani, \\ Email: nishantlt05@gmail.com \\ Copyright: (C) the author(s), publisher and licensee Medip Academy. This is an open-access article distributed under \\ the terms of the Creative Commons Attribution Non-Commercial License, which permits unrestricted non-commercial \\ use, distribution, and reproduction in any medium, provided the original work is properly cited.
}

\begin{abstract}
Background: Cataract is the leading cause of blindness worldwide. Treatment of cataract is surgical. Topical corticosteroids are routinely used in the treatment of post-operative inflammation following cataract surgery. This study aims to compare the intraocular pressure changes caused by topical steroids (dexamethasone and difluprednate) and to detect adverse effects.

Methods: All patients operated by phacoemulsification in ophthalmology Department of SMIMER Surat were taken as subjects. Depending on topical steroids prescribed after surgery, subjects were separated into 2 groups, group 1 difluprednate and group 2 - dexamethasone. Changes in intra-ocular pressure (IOP) of patients were collected from the data available pre-operative, 1 st ,2nd ,3rd ,4th week after surgery and were analyzed. Other parameters whose data were collected are-adverse effects and compliance of patients.

Results: In group 1 preoperative mean IOP was 15.5. At the end of 1 st week, the mean IOP was significantly increased to 15.8. There was equal rise in IOP during 3rd week and 4th week which means that after 3rd week IOP remains stable. In group 2 preoperative mean IOP was 15.4. At the end of 1st, 2nd, 3rd and 4th there was significant increase in IOP as compared to preoperative mean IOP. Adverse effects were reported more in group 2.

Conclusions: In group 1 there was a rise in IOP up to three weeks but after 3rd week IOP remained stable. In group 2 rise in IOP was seen throughout 4 weeks of treatment. Adverse effects seen more in group 2. Compliance of patients was better in group 1 .
\end{abstract}

Keywords: Difluprednate, Dexamethasone, Intra-ocular pressure

\section{INTRODUCTION}

Cataract is opacity of lens. It is the leading cause of blindness worldwide $62.6 \%$. Treatment of cataract is surgical by phacoemulsification (phaco) or SICS (small incision manual cataract surgery). Surgical trauma to the eye initiates an inflammatory reaction topical corticosteroid are routinely used in the treatment of postoperative inflammation following cataract surgery, as well as after most other ocular surgical procedures..$^{1-8}$ In the tertiary care hospital (SMIMER, SURAT) where this study was done both dexamethasone, and difluprednate are routinely being used in the management of postoperative cataract surgery patients.

Aims and objectives of this study were to compare the intraocular pressure changes caused by topical steroids (dexamethasone and difluprednate) in post cataract patients. To compare the compliance of dexamethasone 
and difluprednate in post cataract patients. To detect any significant adverse effects with the use of these drugs.

\section{METHODS}

An observational study of intraocular pressure changes in post-operative cataract patients treated with difluprednate, dexamethasone was carried out at a tertiary care hospital.

It was a randomized observational study conducted after IEC permission during the period April 2016 to March 2017. Total number of patients enrolled in the study were 246. Written informed consent was obtained from all patients. Confidentiality of information was maintained.

Patients above 18 years of age, admitted in ophthalmology department for cataract surgery who were operated only by phacoemulsification and willing to participate in the study were included.

Patients of cataract with diabetes, hypertension and glaucoma were excluded. Patients were selected randomly. Since surgery and the postoperative course of cataract are different in children and adults, children were excluded. Data of 246 patients was collected for this study. Twenty patients were not included in final data analysis as they did not report for follow up.

Depending on topical steroids which were prescribed after surgery, subjects were divided into two groups. The protocol for groups was pre-decided by ophthalmology department as follows. Topical steroids were given 12 hours after surgery in each group. Group 1 patients operated on Mondays were prescribed difluprednate $0.05 \%$ after surgery. Drug was given four times a day for 1 week. Followed by three times a day for 1 week and then twice a day for 2 weeks. Group 2 patients operated on Tuesdays were prescribed dexamethasone $0.3 \%$ after surgery. Drug was given 1 hourly for 1 week. Followed by 2 hourly for 1 week and then four times a day for 2 weeks.

Changes in intra-ocular pressure (IOP) of patients were measured and documented by the ophthalmology department preoperatively and postoperatively after $1^{\text {st }}$, $2^{\text {nd }}, 3^{\text {rd }}$ and $4^{\text {th }}$ week of surgery. The data was collected and analysed to assess if any of the drugs has caused significant change in intra-ocular pressure and whether there was any difference among the test drugs in this regard. Other parameters recorded were adverse effects if any and compliance of patients.

All data were analysed by using statistical software SPSS 16 version and microsoft 2010. Data were analysed by applying paired t test, ANOVA test. P value less than 0.05 was considered as significant in this study.

\section{RESULTS}

\section{Intraocular pressure changes}

\section{Group 1: Difluprednate}

In group 1 pre-operative mean IOP was 15.5. At the end of $1^{\text {st }}$ week, the mean IOP was significantly increased to 15.8 ( $\mathrm{p}$ value 0.025 ). There was also a significant increase in IOP at the end of $2^{\text {nd }}(16.4, p=0.001), 3^{\text {rd }}$ (mean IOP 16.9, $\mathrm{p}$ value 0.001 ) and $4^{\text {th }}$ week (mean IOP 16.9 , $\mathrm{p}$ value 0.001 ) as compared to preoperative mean IOP. This was shown in Table 1 and Figure 1.

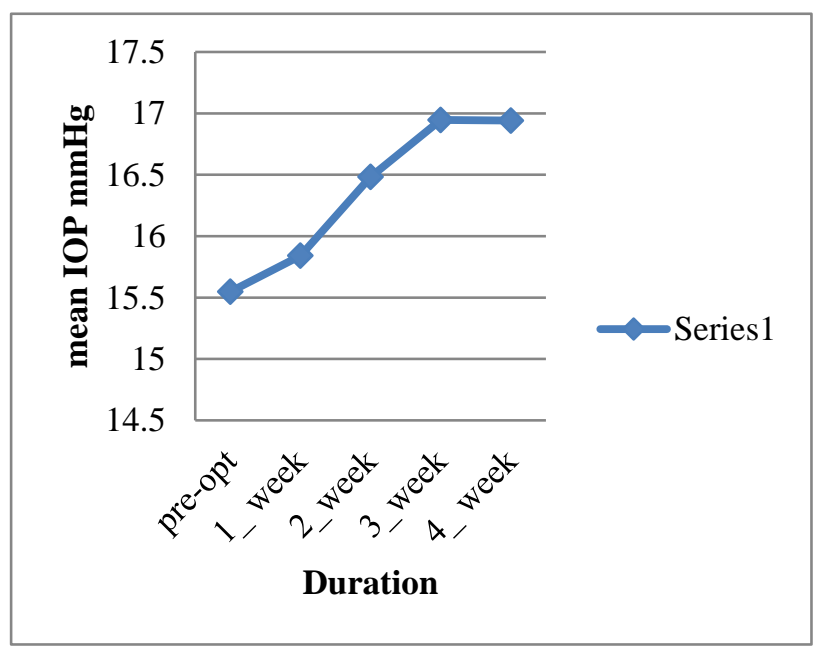

Figure 1: Mean IOP changes of group 1.

Table 1: Comparison of IOP changes in difluprednate group.

\begin{tabular}{|c|c|c|c|c|c|c|}
\hline Pairs & $\begin{array}{l}\text { Duration of } \\
\text { comparison }\end{array}$ & $\begin{array}{l}\text { No. of } \\
\text { patients }\end{array}$ & $\begin{array}{l}\text { Mean IOP } \\
(\mathrm{mmHg})\end{array}$ & SD & $\begin{array}{l}\text { Mean } \\
\text { difference }\end{array}$ & P value \\
\hline \multirow{2}{*}{$\begin{array}{l}\text { Pre-operative } \\
\text { and } 1 \text { week }\end{array}$} & Pre-operative & \multirow{2}{*}{110} & 15.5473 & 2.48543 & \multirow{2}{*}{0.29364} & \multirow{2}{*}{$\mathrm{P}<0.025$} \\
\hline & 1 week & & 15.8409 & 2.60220 & & \\
\hline \multirow{2}{*}{$\begin{array}{l}\text { Pre-operative } \\
\text { and } 2 \text { weeks }\end{array}$} & Pre-operative & \multirow{2}{*}{110} & 15.5473 & 2.48543 & \multirow{2}{*}{0.93455} & \multirow{2}{*}{$\mathrm{P}<0.001$} \\
\hline & 2 weeks & & 16.4818 & 2.66170 & & \\
\hline \multirow{2}{*}{$\begin{array}{l}\text { Pre-operative } \\
\text { and } 3 \text { weeks }\end{array}$} & Pre-operative & \multirow{2}{*}{110} & 15.5473 & 2.48543 & \multirow{2}{*}{1.39909} & \multirow{2}{*}{$\mathrm{P}<0.001$} \\
\hline & 3 weeks & & 16.9464 & 2.88621 & & \\
\hline \multirow{2}{*}{$\begin{array}{l}\text { Pre-operative } \\
\text { and } 4 \text { weeks }\end{array}$} & Pre-operative & \multirow{2}{*}{110} & 15.5473 & 2.48543 & \multirow{2}{*}{1.39364} & \multirow{2}{*}{$\mathrm{P}<0.001$} \\
\hline & 4 weeks & & 16.9409 & 2.77500 & & \\
\hline
\end{tabular}

Paired ' $\mathrm{t}$ ' was applied for comparing IOP changes. $\mathrm{P}<0.05$ was considered to be significant. 
Table 2: Comparison of IOP changes in difluprednate group during four weeks duration of treatment.

\begin{tabular}{|c|c|c|c|c|c|c|}
\hline Pairs & $\begin{array}{l}\text { Duration of } \\
\text { comparison }\end{array}$ & $\begin{array}{l}\text { No. of } \\
\text { patients }\end{array}$ & $\begin{array}{l}\text { Mean IOP } \\
(\mathrm{mmHg})\end{array}$ & SD & $\begin{array}{l}\text { Mean } \\
\text { difference }\end{array}$ & P value \\
\hline \multirow{2}{*}{$\begin{array}{l}1 \text { week and } 2 \\
\text { weeks }\end{array}$} & 1 week & \multirow{2}{*}{110} & 15.8409 & 2.60220 & \multirow{2}{*}{0.64091} & \multirow{2}{*}{$\mathrm{P}<0.001$} \\
\hline & 2 weeks & & 16.4818 & 2.66170 & & \\
\hline \multirow{2}{*}{$\begin{array}{l}1 \text { week and } 3 \\
\text { weeks }\end{array}$} & 1 week & \multirow{2}{*}{110} & 15.8409 & 2.48543 & \multirow{2}{*}{1.10545} & \multirow{2}{*}{$\mathrm{P}<0.001$} \\
\hline & 3 weeks & & 16.9464 & 2.77500 & & \\
\hline \multirow{2}{*}{$\begin{array}{l}1 \text { week and } 4 \\
\text { weeks }\end{array}$} & 1 week & \multirow{2}{*}{110} & 15.8409 & 2.60220 & \multirow{2}{*}{1.10000} & \multirow{2}{*}{$P<0.001$} \\
\hline & 4 weeks & & 16.9409 & 2.77500 & & \\
\hline \multirow{2}{*}{$\begin{array}{l}2 \text { week and } 3 \\
\text { weeks }\end{array}$} & 2 weeks & \multirow{2}{*}{110} & 16.4818 & 2.66170 & \multirow{2}{*}{0.46455} & \multirow{2}{*}{$P<0.001$} \\
\hline & 3 weeks & & 16.9464 & 2.88621 & & \\
\hline \multirow{2}{*}{$\begin{array}{l}2 \text { week and } 4 \\
\text { weeks }\end{array}$} & 2 weeks & \multirow{2}{*}{110} & 16.4818 & 2.66170 & \multirow{2}{*}{0.45909} & \multirow{2}{*}{0.004} \\
\hline & 4 weeks & & 16.9409 & 2.77500 & & \\
\hline \multirow{2}{*}{$\begin{array}{l}3 \text { weeks and } 4 \\
\text { weeks }\end{array}$} & 3 weeks & \multirow{2}{*}{110} & \multirow{2}{*}{16.9464} & \multirow{2}{*}{2.88621} & \multirow{2}{*}{0.00545} & \multirow{2}{*}{0.972} \\
\hline & 4 weeks & & & & & \\
\hline
\end{tabular}

Paired 't' was applied for comparing IOP changes. $\mathrm{P}<0.05$ was considered to be significant.

Table 3: Comparison of IOP changes in dexamethasone group.

\begin{tabular}{|c|c|c|c|c|c|}
\hline Duration of comparison & No. of patients & Mean IOP (mmHg) & SD & Mean difference & P value \\
\hline Pre-operative & \multirow{2}{*}{136} & 15.4029 & 2.26611 & \multirow{2}{*}{0.35809} & \multirow{2}{*}{$\mathrm{P}<0.002$} \\
\hline 1 week & & 15.7610 & 2.41683 & & \\
\hline Pre-operative & \multirow{2}{*}{136} & 15.4029 & 2.26611 & \multirow{2}{*}{0.80147} & \multirow{2}{*}{$\mathrm{P}<0.001$} \\
\hline 2 weeks & & 16.2044 & 2.41948 & & \\
\hline Pre-operative & \multirow{2}{*}{136} & 15.4029 & 2.26611 & \multirow{2}{*}{1.35221} & \multirow{2}{*}{$P<0.001$} \\
\hline 3 weeks & & 16.7551 & 2.38718 & & \\
\hline Pre-operative & \multirow{2}{*}{136} & 15.4029 & 2.26611 & \multirow{2}{*}{1.72426} & \multirow{2}{*}{$\mathrm{P}<0.001$} \\
\hline 4 weeks & & 17.1272 & 2.40855 & & \\
\hline
\end{tabular}

Paired 't' was applied for comparing IOP changes. $\mathrm{P}<0.05$ was considered to be significant.

Table 4: Comparison of IOP changes of dexamethasone during four weeks duration of treatment.

\begin{tabular}{|c|c|c|c|c|c|c|}
\hline Pairs & $\begin{array}{l}\text { Duration of } \\
\text { comparison }\end{array}$ & No. of patients & $\begin{array}{l}\text { Mean IOP } \\
\text { (mmHg) }\end{array}$ & SD & $\begin{array}{l}\text { Mean } \\
\text { difference }\end{array}$ & P value \\
\hline \multirow{2}{*}{$\begin{array}{l}1 \text { week and } 2 \\
\text { weeks }\end{array}$} & 1 week & \multirow{2}{*}{136} & 15.7610 & 2.41683 & \multirow{2}{*}{0.44338} & \multirow{2}{*}{$\mathrm{P}<0.001$} \\
\hline & 2 weeks & & 16.2044 & 2.41948 & & \\
\hline \multirow{2}{*}{$\begin{array}{l}1 \text { week and } 3 \\
\text { weeks }\end{array}$} & 1 week & \multirow{2}{*}{136} & 15.7610 & 2.41683 & \multirow{2}{*}{0.99412} & \multirow{2}{*}{$\mathrm{P}<0.001$} \\
\hline & 3 weeks & & 16.7551 & 2.38718 & & \\
\hline \multirow{2}{*}{$\begin{array}{l}1 \text { week and } 4 \\
\text { weeks }\end{array}$} & 1 week & \multirow{2}{*}{136} & 15.7610 & 2.41683 & \multirow{2}{*}{1.36618} & \multirow{2}{*}{$\mathrm{P}<0.001$} \\
\hline & 4 weeks & & 17.1272 & 2.40855 & & \\
\hline \multirow{2}{*}{$\begin{array}{l}2 \text { weeks and } 3 \\
\text { weeks }\end{array}$} & 2 weeks & \multirow{2}{*}{136} & 16.2044 & 2.41948 & \multirow{2}{*}{0.55074} & \multirow{2}{*}{$\mathrm{P}<0.001$} \\
\hline & 3 weeks & & 16.7551 & 2.38718 & & \\
\hline \multirow{2}{*}{$\begin{array}{l}2 \text { weeks and } \\
4 \text { weeks }\end{array}$} & 2 weeks & \multirow{2}{*}{136} & 16.2044 & 2.41948 & \multirow{2}{*}{0.92279} & \multirow{2}{*}{$\mathrm{P}<0.001$} \\
\hline & 4 weeks & & 17.1272 & 2.40855 & & \\
\hline \multirow{2}{*}{$\begin{array}{l}3 \text { weeks and } 4 \\
\text { weeks }\end{array}$} & 3 weeks & \multirow{2}{*}{136} & 16.7551 & 2.38718 & \multirow{2}{*}{0.37206} & \multirow{2}{*}{$\mathrm{P}<0.001$} \\
\hline & 4 weeks & & 17.1272 & 2.40855 & & \\
\hline
\end{tabular}

Paired ' $\mathrm{t}$ ' was applied for comparing IOP changes. $\mathrm{P}<0.05$ was considered to be significant.

Mean IOP of $1^{\text {st }}$ week 15.8 was compared with $2^{\text {nd }} 16.4$, $3^{\text {rd }}$ IOP 16.9 and $4^{\text {th }}$ week IOP 16.9. There was increase in mean IOP during $2^{\text {nd }}, 3^{\text {rd }}$ and $4^{\text {th }}$ week. There was a highly significant difference ( $p$ value 0.001 ) in these values. Similarly, while comparing $2^{\text {nd }}$ week IOP 16.4 , with $3^{\text {rd }}$ week IOP 16.9 changes there was highly significant difference ( $p$ value 0.001 ).
On comparing mean IOP between $2^{\text {nd }} 16.4$ and $4^{\text {th }}$ week IOP 16.9 there was significant difference ( $p$ value 0.004 ) and on comparing mean IOP between $3^{\text {rd }}$ week and $4^{\text {th }}$ week there was no significant difference ( $\mathrm{p}$ value 0.972 ).

There was equal rise in IOP during $3^{\text {rd }}$ week mean IOP 16.9 and $4^{\text {th }}$ week mean IOP 16.9 which means that after 
$3^{\text {rd }}$ week IOP remains stable, there was no further rise in IOP. This is shown in (Table 2 and Figure 1).

\section{Group 2: Dexamethasone}

In group 2 pre-operative mean IOP was 15.4. At the end of $1^{\text {st }}$ week, the mean IOP was significantly increased to 15.7 ( $\mathrm{p}$ value 0.002). There was also a significant increase in IOP at the end of $2^{\text {nd }}(16.2 \mathrm{p}$ value 0.001$), 3^{\text {rd }}$ (mean IOP 16.7, p value 0.001) and $4^{\text {th }}$ week (mean IOP $17.1, \mathrm{p}$ value 0.001 ) as compared to preoperative mean IOP (Table 3 and Figure 2).

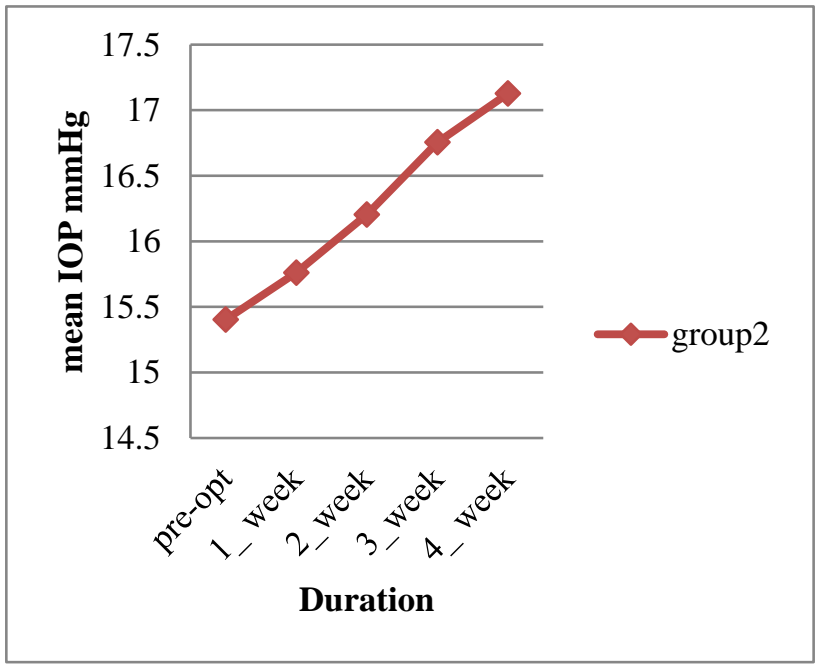

Figure 2: Mean IOP changes of group 2.

Mean IOP of $1^{\text {st }}$ week 15.7 was compared with $2^{\text {nd }}(16.2)$, $3^{\text {rd }}$ (IOP 16.7) and $4^{\text {th }}$ week (IOP 17.1). There was a highly significant difference ( $p$ value 0.001 ) in these values. Similarly, on comparing $2^{\text {nd }}$ week IOP with $3^{\text {rd }}$ and $4^{\text {th }}$ week IOP changes there was highly significant difference ( $\mathrm{p}$ value 0.001). IOP after $3^{\text {rd }}$ week was compared with IOP measured after $4^{\text {th }}$ week, significant increase in IOP was seen ( $p$ value 0.001 ) i.e. $4^{\text {th }}$ week there was more significant rise in IOP as compared to $3^{\text {rd }}$ week.

Table 5: Comparison of frequency of adverse effects of different groups.

\begin{tabular}{|lll|}
\hline Adverse effect & Group 1 & Group 2 \\
\hline Blurring of vision & 0 & 2 \\
\hline Redness of eyes & 1 & 3 \\
\hline Pain & 0 & 11 \\
\hline Itching of eyes & 0 & 10 \\
\hline Dryness of eyes & 0 & 1 \\
\hline Stinging & 0 & 1 \\
\hline Watering of eyes & 3 & 30 \\
\hline
\end{tabular}

\section{Analysis of adverse effects of different steroids}

Group 1 - redness of eyes and watering of eyes were reported. Group 2 - pain, itching of eyes and watering of eyes, blurring of vision were reported, shown in (Table $5)$.

\section{Analysis of compliance of patients}

Compliance of patient was good in group 1. None of the patients missed any dose. In group 2, number of patients who missed one or more doses during $1^{\text {st }}$ week and $2^{\text {nd }}$ week were 19 and 12 respectively.

Compliance of patient was $100 \%$ in group 1 throughout the four weeks' duration of treatment. In group 2 compliance of patient was $86 \%$ in $1^{\text {st }}$ week $91.1 \%$ in $2^{\text {nd }}$ week, and $100 \%$ in $3^{\text {rd }}$ and $4^{\text {th }}$ week.

Table 6: Compliance of patients of different groups.

\begin{tabular}{|c|c|c|c|c|}
\hline \multirow{2}{*}{ Drug } & \multicolumn{4}{|c|}{$\begin{array}{l}\text { Number of patients missed the dose } \\
\text { during subsequent intervals }\end{array}$} \\
\hline & $\begin{array}{l}1^{\text {st }} \\
\text { week }\end{array}$ & $\begin{array}{l}2^{\text {nd }} \\
\text { weeks }\end{array}$ & $\begin{array}{l}3^{\text {rd }} \\
\text { weeks }\end{array}$ & $\begin{array}{l}4^{\text {th }} \\
\text { weeks }\end{array}$ \\
\hline Group 1 & 0 & 0 & 0 & 0 \\
\hline Group 2 & 19 & 12 & 0 & 0 \\
\hline
\end{tabular}

Table 7: Comparison of compliance of patients of different groups.

\begin{tabular}{|lllll|}
\hline Drug & $\begin{array}{l}\mathbf{1}^{\text {st }} \\
\text { week }^{\text {rd }}\end{array}$ & $\begin{array}{l}2^{\text {nd }} \\
\text { weeks } \\
(\%)\end{array}$ & $\begin{array}{l}\mathbf{3}^{\text {rd }} \\
\text { weeks } \\
(\%)\end{array}$ & $\begin{array}{l}\mathbf{4}^{\text {th }} \\
\text { weeks } \\
(\%)\end{array}$ \\
\hline Group 1 & 100 & 100 & 100 & 100 \\
\hline Group 2 & 86 & 91.1 & 100 & 100 \\
\hline
\end{tabular}

\section{DISCUSSION}

Modern cataract surgery yields excellent visual acuity and is a very safe procedure although not free of complications. 9 Topical corticosteroids are commonly used as routine treatment over several weeks to reduce the inflammatory reaction and improve visual outcome after cataract surgery. ${ }^{10}$ Most of the side-effects of topical steroids are related to potency, duration of action and their ability to penetrate through the cornea. ${ }^{11}$ To control ocular inflammation, in disease, following trauma and for prevention of inflammation after eye surgery, topical corticosteroids are considered to be the strongest and fastest acting anti-inflammatory agents. Steroids should not be avoided simply because of side effects and must be used judiciously to attain maximum benefits without any side effects. ${ }^{12}$

Our study has shown that difluprednate is well tolerated and has lesser side effects. Results of a study by Mochizuki et al were similar to our study. This study was conducted to assess the safety and efficacy of difluprednate ophthalmic emulsion (DFBA 0.05\%) in severe endogenous anterior uveitis. ${ }^{13} \mathrm{~A}$ study done by with Patil et al in 90 patients to compare the antiinflammatory efficacy of steroids after 
phacoemulsification showed that all steroids are equally efficacious in controlling inflammation but difluprednate was found to control inflammation more rapidly. ${ }^{14}$

Ohno et al conducted study of difluprednate ophthalmic emulsion $0.05 \%$ in the treatment of anterior uveitis and their study showed that difluprednate is not inferior to other steroids and has an acceptable safety level. ${ }^{15}$ Similar results were obtained in our study.

\section{CONCLUSION}

The results show that both the topical steroids cause a rise in intraocular pressure in post cataract patients. In group 1 (difluprednate) there was a rise in IOP up to three weeks after surgery but after $3^{\text {rd }}$ week IOP remained stable. In group 2 (dexamethasone) rise in IOP was seen throughout the 4 weeks of treatment. Adverse effects were more in group 2 and in comparison, to group 1 . Compliance of patients was better in group 1 compared to group 2 .

\section{Funding: No funding sources}

Conflict of interest: None declared

Ethical approval: The study was approved by the Institutional Ethics Committee

\section{REFERENCES}

1. The Loteprednol Etabonate Post-operative Inflammation Study Group 2. A double-masked, placebo-controlled evaluation of $0.5 \%$ loteprednol etabonate in the treatment of post-operative inflammation. The Loteprednol Etabonate Postoperative Inflammation Study Group 2. Ophthalmology. 1998;105:1780-6.

2. Bron A, Denis P, Xuan HTC. The effects of rimexolone $1 \%$ in postoperative inflammation after cataract extraction. A double-masked placebocontrolled study. Eur J Ophthalmol. 1998;8:16-21.

3. Korenfeld MS, Silverstein SM, Cooke DL, Vogel R, Crockett RS. Difluprednate ophthalmic emulsion $0.05 \%$ for postoperative inflammation and pain. J Cataract Refract Surg. 2009;35:26-34.

4. Stewart R, Horwitz B, Howes J, Novack GD, Hart K. Double-masked, placebo-controlled evaluation of loteprednol etabonate $0.5 \%$ for postoperative inflammation. Loteprednol Etabonate Post-operative Inflammation Study Group 1. J Cataract Refract Surg. 1998;24:1480-9.

5. Campos M, Avila M, Wallau A, Muccioli C, Lima HAL, Belfort R. Efficacy and tolerability of a fixeddose moxifloxacin-dexamethasone formulation for topical prophylaxis in LASIK: a comparative, double-masked clinical trial. Clin Ophthalmol. 2008;2:331-8.

6. Holland EJ, Djalilian AR, Sanderson JP. Attenuation of ocular hypertension with the use of topical loteprednol etabonate $0.5 \%$ in steroid responders after corneal transplantation. Cornea. 2009;28:113943.

7. Seah SK, Husain R, Gazzard G. Use of surodex in phacotrabeculectomy surgery. Am J Ophthalmol. 2005;139:927-8.

8. Vetrugno M, Maino A, Quaranta GM, Cardia L. The effect of early steroid treatment after PRK on clinical and refractive outcomes. Acta Ophthalmol Scand. 2001;79:23-7.

9. Neil RP, Schein OD, Gieser SC. Synthesis of the Literature on Visual Acuity and Complications Following Cataract Extraction with Intraocular. Lens Implantation Arch Ophthalmol. 1994;112(2):239-52.

10. Laurell CG, Zetterstrom C. Effects of dexamethasone, diclofenac, or placebo on the inflammatory response after cataract surgery. $\mathrm{Br} \mathrm{J}$ Ophthalmol. 2002;86:1380-4.

11. Garrick C, Kiely AE, Challa P. Topical Corticosteroid and NSAID Therapies for Ocular Inflammation. Cataract Refractive Surg Today. 2014:15-20.

12. Hazarika AK. Benefits and Risk of Topical Corticosteroids in the Management of ocular Inflammation. SMU Med J. 2015;2(2):1604-2349.

13. Mochizuki M, Ohno S, Usui M, Masuda K, Sekiya T, Ogawa T, et al. A Phase III, Open-Label, Clinical Study of Difluprednate Ophthalmic Emulsion (DFBA), $0.05 \%$, in the Treatment of Severe Refractory Anterior Uveitis. Investigative Ophthalmology Visual Sci. 2007;48:3905.

14. Patil A, Gupta V, Sethi H, Nehate R. A comparative evaluation of anti-inflammatory efficacy of various ophthalmic steroids in post phaco-emulsification patients. ESCRS. 2016;9(3):150-6.

15. Ohno S, Mochizuki M, Usui M, Miyake S, Nagai N, Ozawa Y, et al. A phase III noninferiority study of difluprednate ophthalmic emulsion $0.05 \%$ in the treatment of anterior uveitis. Invest Ophthalmol Vis Sci. 2012;53(14):2568.

Cite this article as: Hingorani SK, Desai AS, Shastri MB. An observational comparative study of intraocular pressure changes in post-operative cataract patients treated with dexamethasone and difluprednate. Int J Basic Clin Pharmacol 2020;9:1079-83. 